\title{
Pengaruh Pendekatan Kontekstual dalam Motivasi Belajar Siswa Sekolah Menengah Pertama
}

\author{
Sukma Nurmawarni \\ Mahasiswa Pendidikan IPA/Pendidikan MIPA, Fakultas Keguruan dan Ilmu Pendidikan, Universitas \\ Jember, Indonesia \\ E-mail: sukmanurama@gmail.com
}

\begin{abstract}
This study has the aim of knowing students' understanding and motivation with the CTL approach. In the learning process is bound to the learning approach so that the learning process can run optimally, fun and full of meaning. In contextual learning students must connect knowledge through material provided by educators and connect with real life. Data collection was carried out by giving questionnaires to students' subjects from SMPN 1 Sukorambi. If you use the CTL method, students' memory will become strong and will not be forgotten.
\end{abstract}

Keywords: students, CTL, meaningful learning.

\section{PENDAHULUAN}

Belajar merupakan suatu proses dalam membangun gagasan bagi peserta didik, maka kegiatan pembelajaran hendaknya memberikan kesempatan pada peserta didik untuk melakukan hal tersebut secara lancar dan termotivasi. Suasana belajar yang diciptakan guru harus melibatkan peserta didik secara aktif, misal mengamati, bertanya dan mempertanyakan, menjelaskan, dan sebagainya (Mulyono, 2012 : 39).

Konsep dasar Contextual Teacher and Learning (CTL) merupakan proses pendidikan yang bertujuan untuk menolong peserta didik melihat makna pada materi akademik yang telah mereka pelajari dengan menghubungkan subjek akademik dengan konteks dalam kehidupan sehari - hari. Pendekatan yang cocok dan paling efektif sesuai dengan kondisi karakteristik sikap budaya di Indonesia adalah pendekatan yang mencangkup kesesuaian antar situasi dan belajar peserta didik dengan kehidupan sehari - hari (Yulindaria, 2017). Pengajaran konstektual merupakan pengajaran yang membuat peserta didik mampu memperkuat, mengembangkan, dan menerapkan pengetahuan dan keterampilan akademik peserta didik di lingkungan sekolah maupun luar sekolah untuk memecahkan suatu permasalahan yang nyata maupun simulasi. Pembelajaran ini terjadi ketika peserta didik mengalami, kemudian menerapkan hal yang mereka pelajari dengan merujuk pada permasalahan nyata yang berhubungan dengan peran dan tanggung jawab mereka. CTL menekankan pada tingkat pemikiran yang lebih tinggi, alih pengetahuan antarmata pelajaran akademis, serta menghubungkan, menganalisis, dan menyusun informasi dan data dari berbagai sumber dan sudut pandang (Alwasilah, 2007 : 309).

Karakteristik dari pembelajaran kontekstual: Pertama, pembelajaran dilaksanakan dalam konteks autentik, yaitu pembelajaran yang diarahkan pada ketercapaian keterampilan dalam konteks kehidupan nyata atau pembelajaran yang dilaksanakan dalam lingkungan yang alamiah (learning in real life setting). Kedua, pembelajaran memberikan kesempatan kepada siswa untuk mengerjakan tugastugas yang bermakna (meaningful learning) . Ketiga, pembelajaran dilaksanakan dengan memberikan pengalaman bermakna kepada siswa (learning by doing). Keempat, pembelajaran dilaksanakan melalui kelompok, berdiskusi, saling mengoreksi antar teman (learning in a group). Kelima, pembelajaran memberikan kesempatan untuk menciptakan rasa kebersamaan, kerjasama, dan saling memahami antara satu dengan yang lain secara mendalam (learning to know each other deeply). Keenam, pembelajaran dilaksanakan secara aktif, kreatif, produktif dan mementingkan kerja sama (leraning to ask, to inguiry, to work 
together). Ketujuh, pembelajaran dilaksanakan dalam situasi yang menyenangkan (learning as an enjoy activity).

Pentingnya lingkungan belajar dalam pembelajaran kontekstual salah satunya yaitu, belajar efektif itu dimulai dari lingkungan belajar yang berpusat pada siswa. Dari "guru akting di depan kelas, siswa menonton" ke "siswa aktif bekerja dan berkarya, guru mengarahkan". Pembelajaran harus berpusat pada "bagaimana cara" siswa menggunakan pengetahuan baru mereka. Strategi belajar lebih dipentingkan dibandingkan hasilnya. Umpan balik amat penting bagi siswa yang berasal dari proses penilaian (assesment) yang benar. Menumbuhkan komunitas belajar dalam bentuk kerja kelompok itu penting.

Langkah - langkah pendekatan kontekstual, pendidik harus membuat skenario pembelajaran sebagai pedoman umum dan sekaligus sebagai alat kontrol dalam pelaksanaannya. Berikut langkah langkah dalam pembelajaran kontekstual : Pertama, mengembangkan pemikiran siswa bahwa dia akan belajar lebih bermakna dengan cara bekerja sendiri, menemukan sendiri, dan mengonstruksikan sendiri pengetahuan dan keterampilan barunya. Kedua, kelaksanakan sejauh mungkin kegiatan inkuiri semua topik. Ketiga, mengembangkan sifat ingin tahu siswa dengan bertanya. Keempat, menciptakan masyarakat belajar. Kelima, menghadirkan model sebagai contoh pembelajaran. Keenam, melakukan refleksi diakhir pertemuan. Ketujuh, melakukan penilaian yang sebenarnya dengan berbagai cara.

Kelebihan pendekatan kontekstual antara lain, pembelajaran lebih bermakna, siswa melakukan sendiri kegiatan yang berhubungan dengan materi yang ada sehingga siswa dapat memahaminya sendiri. Kedua, pembelajaran lebih produktif dan mampu menumbuhkan penguatan konsep kepada siswa karena pembelajaran kontekstual menuntut siswa menemukan sendiri bukan menghafal. Ketiga, menumbuhkan keberanian siswa mengemukakan pendapat tentang materi yang dipelajari. Keempat, menumbuhkan rasa ingin tahu tentang materi yang dipelajari dengan bertanya kepada guru. Kelima, menumbuhkan kemampuan dalam bekerjasama dengan teman yang lain untuk memecahkan masalah yang ada. Keenam, siswa dapat membuat kesimpulan sendiri kegiatan pembelajaran.

Sedangkan kelemahan dari pendekatan kontekstual yaitu, bagi siswa yang tidak dapat mengikuti pembelajaran, tidak dapat mendapatkan pengetahuan dan pengalaman yang sama dengan teman lainnya karena siswa tidak mengalami sendiri. Kedua, perasaan khawatir pada anggota kelompok akan hilangnya karakteristik siswa karena harus menyesuaikan dengan kelompoknya. Ketiga, banyak siswa yang tidak suka jika disuruh bekerjasama dengan yang lain, karena siswa yang tekun merasa harus bekerja melebihi siswa yang lain dalam kelompoknya.

Dalam pembelajaran konstektual terdapat beberapa komponen yaitu : making meaning connection (menjalin hubungan hubungan yang bermakna), doing significan work (mengerjakan pekerjaan - pekerjaan yang berarti), self-regulated learning (melakukan proses belajar yang diatur sendiri), collaborating (mengadakan kolaborasi), critical and creatif thingking (berpikir kritis dan kreatif), nurturing the individual (memberikan layanan secara individual), reaching high standards (mengupayakan pencapaian standar yang tinggi), dan using authentic assessment (menggunakan asesmen autentik) (Rusman, $2017: 324)$.

Keberhasilan dalam belajar, selain menggunakan pendekatan dan metode yang tepat juga membutuhkan motivasi siswa untuk belajar. Jika siswa memiliki motivasi, dan bersemangat dalam pembelajaran maka proses belajar mengajar akan berjalan dengan lancar. Ada banyak cara yang dapat dilakukan untuk meningkatkan motivasi belajar diantaranya dengan memberikan variasi dalam metode pembelajaran dan dengan mengkaitkan materi dengan kehidupan sehari - hari siswa dengan metode pembelajaran kontekstual (Pramitasari, 2011).

Menurut teori Piaget, tentang proses perkembangan kognitif mengatakan struktur kognitif yang kita miliki selalu berinteraksi 
dengan lingkungannya dengan cara asimilasi dan akomodasi. Jika asimilasi dan akomodasi terjadi secara bebas atau tanpa konflik, maka struktur kognitif dikatakan berada pada keadaan seimbang (equilibrium) dengan lingkungannya. Namun, jika terjadi konflik maka seseorang berada pada keadaan tidak seimbang (disequilibrium). Hal ini terjadi karena skema yang masuk tidak sama dengan struktur (skema) kognitif yang dimilikinya. Ketika seorang berada pada keadaan disequilibrium, dia akan merespon keadaan ini, dan berupaya mengingat, memberdayakan konsep yang dimilikinya untuk mencari equilibrium baru dengan lingkungannya. Melalui metakognisi, bertanya pada teman yang tidak mengalami konflik, atau scaffolding yang diberikan guru maka siswa dapat keluar dari konflik. Jadi, konflik kognitif merupakan syarat awal atau stimulus dalam memperoleh keseimbangan (equilibrium) baru. Tingkat keseimbangan (equilibrium) baru ini lebih tinggi tingkatannya dari keseimbangan (equilibrium) sebelumnya (Ismaimuza, 2010).

\section{METODE PENELITIAN}

\section{Tempat dan Waktu Penelitian}

Penelitian dilaksanakan pada hari Sabtu, 27 Oktober 2018 di SMPN 1 Sukorambi.

\section{Populasi dan Sampel}

Populasi adalah semua individu yang menjadi sumber dalam pengambilan sampel. Sampel pada penelitian ini pada kelas VIII B SMPN 1 Sukorambi yang berjumlah 27 siswa.

\section{Teknik Pengumpulan Data}

Teknik dalam pengambilan data dilakukan dengan cara memberikan angket kepada siswa kelas VIII B. Angket berisi pertanyaan yang digunakan untuk mendapatkan data. Angket yang digunakan berisi 5 pertanyaan dan 3 pilihan jawaban.

\section{Analisis Data}

Analisis terhadap data tersebut yang dilakukan dengan metode analisis deskriptif dengan menemukan masalah dan solusi yang tepat untuk mengatasi.

\section{Kesimpulan dan Saran}

Dalam pegambilan kesimpulan berdasarkan hipotesis, hasil analisa dan pembahasan.

\section{HASIL DAN PEMBAHASAN}

Dalam proses belajar mengajar terdapat interaksi antara pendidik dengan peserta didik. Tujuan utama dari pendekatan kontekstual yaitu agar siswa dapat memahami materi dengan mudah, maka guru tidak hanya menjelaskan materi dari buku saja melainkan dengan menggunakan model atau contoh nyata dalam kehidupan disekitar peserta didik.

Pembelajaran kontekstual menitiberatkan pada hubungan antara materi yang dipelajari peserta didik dengan pengaplikasiannya dalam kehidupan sehari - hari. Motivasi belajar siswa dapat menurun jika siswa tidak dapat melihat bagaimana teori dapat diaplikasikan dalam disiplin ilmu dan pekerjaan. Dengan mengetahui nilai dan kegunaan dari tiap mata pelajaran dan bagaimana cara pengaplikasiannya dalam kehidupan sehari - hari, siswa akan menjadi lebih tertarik sehingga dapat meningkatkan motivasi belajar siswa.

Melalui contextual teaching and learning motivasi belajar siswa dapat meningkat. Faktor yang mempengaruhi motivasi belajar adalah relevance, yang dapat membantu siswa dalam mengetahui kemampuan dan pengaplikasian yang dapat mereka lakukan dalam kehidupan sehari - hari sehingga dapat meningkatkan motivasi belajar siswa tersebut. Relevance dapat dibangun dengan cara mengaplikasikan teori dengan praktek, membangun relevance melalui kasus lokal, menghubungkan materi dengan kehidupan sehari - hari, dan menghubungkan isu yang ada yang dapat ditemukan dalam metode pembelajaran kontekstual.

Motivasi siswa dapat menurun jika siswa tidak dapat melihat bagaimana cara mengaplikasikan materi yang mereka terima disekolah dengan kehidupan sehari - hari. Metode pembelajaran kontekstual terdiri dari delapan komponen yaitu : membuat keterkaitan yang bermakna, melakukan pembelajaran yang berarti, melakukan pekerjaan yang diatur sendiri, bekerja sama, berpikir kritis dan kreatif, membatu individu 
tumbuh dan berkembang, mencapai satndar yang tinggi, dan menggunakan penilaian autentik.

Menurut siswa mengenai efisien dan efektifnya suatu metode pembelajaran ikut mempengaruhi motivasi belajar siswa. Ketika siswa merasa metode pembelajaran efektif dan efisien maka akan meningkatkan motivasi belajar siswa dan sebaliknya jika siswa merasa metode tersebut tidak efektif dan tidak efisien maka motivasi belajar siswa akan menurun.

Berikut merupakan hasil rekapitulasi angket yang telah diberikan kepada siswa kelas VIII B di SMPN 1 Sukorambi.

Tabel 1.1 Hasil Rekapitulasi Respon dari Siswa

\begin{tabular}{|l|c|c|c|}
\hline \multicolumn{1}{|c|}{ Pertanyaan } & Sering & $\begin{array}{c}\text { Kadang- } \\
\text { kadang }\end{array}$ & $\begin{array}{c}\text { Tidak } \\
\text { pernah }\end{array}$ \\
\hline $\begin{array}{l}\text { Apakah mata pelajaran sains merupakan mata pelajaran } \\
\text { yang menarik? }\end{array}$ & 4 & 19 & 4 \\
\hline $\begin{array}{l}\text { Jika disekitar rumahmu ada kejadian alam seperti hujan, } \\
\text { pelangi dll. pernahkan kamu mengkaitkan dengan mata } \\
\text { pelajaran sains? }\end{array}$ & 2 & 17 & 8 \\
\hline $\begin{array}{l}\text { Apakah guru sering melakukan pembelajaran dilingkungan } \\
\text { sekitar pada mata pelajaran sains? }\end{array}$ & 4 & 12 & 11 \\
\hline $\begin{array}{l}\text { Apakah kalian pernah berpikir bahwa percobaan tersebut } \\
\text { berkaitan dengan kehidupan sehari-hari? }\end{array}$ & 4 & 14 & 9 \\
\hline $\begin{array}{l}\text { Apakah kamu suka jika setiap materi menggunakan } \\
\text { pengaplikasiannya dalam kehidupan sehari-hari? }\end{array}$ & 5 & 4 & 18 \\
\hline
\end{tabular}

Berdasarkan data yang diperoleh dari pemberian angket kepada siswa, diketahui bahwa siswa didalam kelas tersebut belum pernah diberi pendekatan kontekstual sehingga siswa disana masih belum mengetahui materi yang diajarkan dan kaitannya dalam kehidupan sehari - hari. Didapati juga ada beberapa siswa yang tidak pernah mengkaitkan materi yang telah diajarkan dengan kehidupan sehari - hari, ini berarti siswa tersebut belum dapat berpikir kritis tentang fenomena yang ada disekitarnya. Menurut angket yang telah diisi oleh siswa, banyak dari mereka yang tidak suka jika materi pembelajaran dikaitkan dengan peristiwa atau pengaplikasiannya dalam kehidupan, hal ini terjadi karena siswa tersebut tidak mengetahui manfaat dari mengkaitkan materi dengan kehidupan nyata sehingga membuat motivasi siswa tidak muncul atau motivasinya masih sedikit dalam menghubungkan materi dengan kehidupan sehari - hari. Berdasarkan data yang diperoleh, diketahui bahwa motivasi siswa dalam mengkaitkan materi dengan realita tidak muncul, atau motivasinya masih kurang. Menurut data, guru di sekolah tersebut kurang menerapkan pendekatan kontekstual, kemungkinan mengapa pendekatan kontekstual ini tidak diterapkan karena perkembangan kemampuan berpikir siswa yang belum dapat menjangkau pola berpikir dengan mengkaitkan materi dengan realita yang ada. Perkembangan kognitif siswa SMP dalam tahap pertumbuhan formal. Seharusnya pada periode ini, siswa sudah memiliki pola pikir untuk memecahkan masalah yang kompleks dan abstrak, memproses informasi dan juga dapat beradaptasi dengan lingkungannya.

Banyak cara efektif untuk mengkaitkan pengajaran dan pembelajaran dengan konteks situasi sehari - hari agar peserta didik tidak bosan, perlu metode yang paling efektif untuk menyatukan materi atau isi akademik dengan konteks pengalam pribadi peserta didik. Menurut buku Johnson dalam buku CTL (2014) terdapat enam metode antara lain :

Pertama, ruang kelas tradisional yang mengkaitkan materi dengan konteks peserta didik. Contohnya, seorang guru ilmu pengetahuan di sekolah menengah, meminta 
tim yang terdiri dari dua siswa secara bergiliran untuk menentukan pembicara tamu mana yang akan bersedia menjelaskan topik yang sedang mereka pelajari. Siswa yang mendapat kesempatan untuk mencari pembicara tamu harus menelepon pembicara tersebut, menentukan tanggalnya, menyambut pembicara tersebut di depan pintu sekolah pada hari $\mathrm{H}$ dan menulis ucapan terima kasih sesudah acara selesai.

Kedua, memasukkan materi dari bidang lain dalam kelas. Materi dapat disisipkan dalam kelas dengan banyak cara. Tugas membaca, topik diskusi khusus, dan proyek langsung merupakan metode - metode yang terkenal untuk memasukkan materi ke dalam satu mata pelajaran.

Ketiga, mata pelajaran yang tetap terpisah tetapi mencangkup topik yang saling berhubungan. Mata pelajaran yang saling berhubungan adalah mata pelajaran terpisah yang disatukan oleh materi yang saling melengkapi dan topik yang sama. Walaupun tiap mata pelajaran memiliki tujuan, penilaian dan nilai akhir yang terpisah, isi setiap pelajaran dihubungkan sedemikian rupa sehingga memberikan konteks pelajaran yang kaya. Guru dari mata pelajaran yang saling berhubungan berunding untuk memastikan bahwa materi di satu kelas melengkapi dan memperkukuh proses belajar yang terjadi di kelas yang lain. Mata pelajaran yang saling berhubungan, mata pelajaran terpisah yang proyek dan tugasnya sama, memungkinkan para siswa untuk melihat bagaimana satu mata pelajaran berhubungan dengan mata pelajaran yang lain.

Keempat, mata pelajaran gabungan yang menyatukan dua atau lebih disiplin ilmu. Di sebuah sekolah menegah pertama, siswa kelas 7 mengambil mata pelajaran terpadu yang menggabungkan ilmu pengetahuan, matematika, bahasa dan sastra, dan ilmu sosial. Kelas tersebut diasuh oleh satu tim guru, pada akhir semester siswa mempertunjukkan pengetahuan mereka sebagian dengan menulis, memproduksi dan menampilkan drama kontemporer tentang salah satu masalah atau topik yang dipilih.

Kelima, menggabungkan sekolah dengan pekerjaan (pembelajaran berbasis pekerjaan, jalur karier, dan pengalaman kerja berbasis sekolah). Menghubungkan sekolah dengan pekerjaan secara hati - hati dengan memberikan unsur - unsur CTL memberi semua siswa gerbang menuju masa depan. Menghubungkan sekolah dengan pekerjaan memberi siswa pilihan untuk mendapatkan gelar teknik-profesional dalam dua tahun, mengikuti kuliah di perguruan tinggi selama empat tahun, dan lain sebagainya. Menghubungkan sekolah dengan pekerjaan mempersiapkan semua siswa untuk membuat pilihan di antara alternatif itu. CTL memberi anak masa depan yang menjanjikan.

Keenam, model kuliah kerja nyata atau penerapan terhadap hal - hal yang dipelajari di sekolah ke masyarakat. Metode ini mengajarkan siswa bahwa mereka bertanggung jawab tidak hanya pada diri mereka sendiri, tetapi pada konteks mereka sebagai seorang manusia yang berada di dalam sebuah jaringan keterkaitan yang menyatukan mereka dengan semua hal (untuk metode keenam ini digunakan untuk jenjang yang lebih tinggi dari sekolah menengah pertama).

\section{SIMPULAN}

Berdasarkan pembahasan diatas, dapat diperoleh kesimpulan sebagai berikut :

Pembelajaran kontekstual lebih baik dalam meningkatkan pemahaman siswa akan materi dan model pembelajaran ini juga mengkaitkan materi yang telah siswa pelajari dengan kehidupan sehari - hari. Siswa juga dapat mengetahui bukti nyata dari materi yang telah diberikan oleh guru, sehingga dapat meningkatkan pemahaman dan daya ingat siswa. Namun pada siswa SMP 1 Sukorambi pendekatan kontekstual belum diterapkan, sehingga banyak siswa yang belum tahu keterkaitan antara materi pembelajaran dengan konsep nyata dalam kehidupan sehari - hari sehingga motivasi belajar dalam mengkaitkan materi dengan realita yang ada tidak muncul.

\section{SARAN DAN UCAPAN TERIMA KASIH}

Saran yang dapat penulis sampaikan yaitu, dengan adanya pendekatan kontekstual diharapkan peserta didik mampu dan memahami kaitan dari materi dengan pengaplikasiannya dalam kehidupan sehari - 
hari. Dengan konsep ini diharapkan hasil pembelajaran lebih bemakna bagi peserta didik. Banyak pihak yang telah membantu dalam penulisan artikel ilmiah ini, penulis mengucapkan terima kasih terhadap pihak yang telah membantu demi kelancaran penulisan artikel ilmiah ini.

\section{DAFTAR PUSTAKA}

Alwasilah. 2007. Contextual Teaching And Learning : Menjadikan Kegiatan Belajar-Mengajar Mengasyikkan dan Bermakna. Bandung : MLC

Amir. 2015. Pengaruh Pembelajaran Kontekstual Terhadap Kemampuan Pemecahan Masalah Matematika Siswa Sekolah Dasar. Fakultas Keguruan dan Ilmu Pendidikan Universitas Muhammadiyah Sidoarjo.

Hasbullah. 2001. Dasar - Dasar Ilmu Pendidikan. Jakarta : PT Raja Grafindo Persada.

Ismaimuza. 2010. Pengaruh Pembelajaran Berbasis Masalah Dengan Strategi Konflik Kognitif Terhadap Kemampuan Berpikir Kritis Matematis dan Sikap Siswa SMP. Jurnal Pendidikan Matematika Vol 4 No. 1

Mulyono. 2012. Strategi Pembelajaran. Malang : UIN-MALIKIPRESS

Pramitasari.Amelia. 2011. Hubungan Antara Persepsi Terhadap Metode Pembelajaran Kontekstual Dengan Motivasi Belajar Biologi Siswa Kelas XI IPA SMAN 1 Pangkalan Kerinci, Riau. Jurnal Psikologi Undip Vol.9 No. 1 : 94

Pujiwati. 2008. Penerapan Pendekatan Contextual Teaching and Learning (CTL) dalam Pembelajaran Berpidato (Suatu Penelitian Tindakan Kelas di SMP Negeri 1 Kalimanah-Purbalingga). Universitas Sebelas Maret

Rusman. 2017. Belajar dan Pembelajaran Berorientasi Standar Proses Pendidikan. Jakarta : Kencana
Susanto. 2014. Pengembangan Pembelajaran IPS di Sekolah Dasar. Jakarta : Prenamedia Group

Yulindaria. 2017. Penerapan Pendekatan Contextual Teaching and Learning (CTL) untuk Meningkatkan Hasil Belajar Siswa pada Materi Energi Gerak dalam Pembelajaran IPA Sekolah Dasar (Penelitian Tidakan Kelas Dilakukan Pada Siswa Kelas III SD Plus 2 AlMuhajirin Kecamatan Purwakarta Kabupaten Purwakarta).

Eduscience Vol. I. No. 1 Desember 2018

Received 10 October $2018 \mid$ Received in revised form 11 November2018| Accepted 25 November $2018 \mid$ Published online 31 December 2018 